\title{
Milk performance of dairy cows supplemented with a combination of slow-release nitrogen and exogenous fibrolytic enzyme
}

\author{
Vimlesh C Sharma ${ }^{1}$, Sudhir K Singh ${ }^{1}$, MS Mahesh ${ }^{1,2}$, Srilatha Atmakuri $^{1}$, B Chandran ${ }^{1}$ and U Balakrishnan ${ }^{1}$
}

Received: 14 December 2020 / Accepted: 13 April 2021 / Published online: 27 July 2021

(C) Indian Dairy Association (India) 2021

\begin{abstract}
The purpose of this on-farm trial was to evaluate the impact of supplementing slow-release nitrogen (SRN; $\min .40 \%$ $\mathrm{N}$ ) and exogenous fibrolytic enzyme (EFE; cellulase, xylanase, glucanase, mannanase and xylanase-potentiating factor) products on milk yield and composition in dairy cows. Twelve early-tomidlactating crossbred cows were divided into 2 groups with comparable milk production. Animals were fed on a total mixed ration comprising of green maize, wheat straw and concentrate mixture. Group $T_{1}$ was supplemented with urea at $80 \mathrm{~g} / \mathrm{animal} / \mathrm{d}$, whereas that of $T_{2}$ received a novel combination of cellulopolymer-coated SRN at $80 \mathrm{~g}$ and EFE at $4 \mathrm{~g} /$ animal/d for a period of 20 days. Results showed no difference in milk yield (13.8 vs. $15.1 \mathrm{~kg} / \mathrm{d} ; \mathrm{P}=0.559)$ between the groups; however, milk fat (3.49 vs. $3.87 \%)$ and solid not fat (7.92 vs. $8.35 \%)$ levels were higher $(\mathrm{P}<0.05)$ in group $\mathrm{T}_{2}$ than $\mathrm{T}_{1}$. Furthermore, on applying 2-axis milk payment system, group $\mathrm{T}_{2}$ demonstrated a return on investment of $8.3: 1$. It was, therefore, concluded that supplementing a combination of SRN and EFE carries practical worth to enhance milk composition, thereby boosting economic gain in dairy farming under Indian context.
\end{abstract}

Keywords: Farm profitability, Fibrolytic enzyme, Milk production, Nutrient synchrony, Slow-release nitrogen

\footnotetext{
${ }^{1}$ Kemin Industries South Asia Pvt. Ltd., Ambattur Industrial Estate, Chennai-600 058, Tamil Nadu, India

${ }^{2}$ Livestock Farm Complex, Faculty of Veterinary and Animal Sciences, Banaras Hindu University, Mirzapur-231 001, Uttar Pradesh, India

MS Mahesh $(\square)$

Livestock Farm Complex, Faculty of Veterinary and Animal Sciences, Banaras Hindu University, Mirzapur-231 001, Uttar Pradesh, India Email: drmaheshmsvet@gmail.com; Telephone: 7309630890
}

Feeding a balanced diet adequate in all essential nutrients is the cornerstone of productive performance of dairy animals. Protein sources are considered as the most expensive ingredient components in dairy rations. However, ruminants can utilise nonprotein nitrogen (NPN) in presence of available fermentable energy to synthesise rumen microbial crude protein (MCP; AFRC, 1993; NRC, 2001). The MCP is of high nutritional significance, given the fact that it could meet as much as $70-100 \%$ of protein requirements of cows depending on the level of productivity (Thirumalesh and Krishnamoorthy, 2013). While urea is the most commonly employed NPN source, due to its instant solubility and ammonia $\left(\mathrm{NH}_{3}\right)$ release in the rumen, it becomes a real challenge to achieving optimum synchrony with that of carbohydrate sources to maximise MCP production (Inostroza et al. 2010; Salami et al. 2021). Consequently, $\mathrm{NH}_{3}$ that is not captured by microbial cells would get absorbed across ruminal wall and excreted (wasted) through urine. On the other hand, if urea is made to deaminate slowly - thus controlling $\mathrm{NH}_{3}$ release over a sustained period of time in the rumen - it could theoretically enhance the yield of MCP (AFRC, 1993; NRC, 2001; Cherdthong and Wanapat, 2010), minimise urinary $\mathrm{N}$ losses and safeguard the health of dairy cows from possible adverse effects of urea (Salami et al. 2021). It is interesting that on 'protein equivalent' basis, $1 \mathrm{~kg}$ of slow-release $\mathrm{N}$ (SRN) could equate to $5-7 \mathrm{~kg}$ of traditional oilseed cakes/meals, and hence appears to lessen the feed cost.

Although rumen represents a fountain of enzyme systems, there seems a limitation for the digestion of lignocellulosic fibre fractions, owing to the highly recalcitrant structure of forage cell walls (Mahesh and Mohini, 2013). Hence, researchers have explored the possibility to improve fibre utilisation and subsequent performance with the use of exogenous fibrolytic enzymes (EFE; Gado et al. 2009; Shekhar et al. 2010; Meale et al. 2014) under diverse dietary and productivity scenarios (TiradoGonzález et al. 2018).

Considering the above points, it was our general hypothesis that supplementing novel feed additives influencing protein and energy metabolism could boost production, whilst also impacting bottom-line farm profits. The objective of the present experiment 
was to assess the response of dairy cows supplemented with a combination of SRN and EFE under field conditions.

This trial was performed at a commercial dairy farm located in north India. Twelve crossbred cows in their early-to-midlactation stage were selected and stratified into 2 groups $\left(\mathrm{T}_{1}\right.$ and $\left.\mathrm{T}_{2}\right)$ of 6 each in such a way that both had similar milk yield before commencement of the trial. All the animals were fed a total mixed ration comprising of specified proportion of chopped green maize $(18.3 \%$ dry matter, $8.2 \%$ crude protein and $42 \%$ neutral detergent fibre), concentrate mixture $(20.8 \%$ crude protein, $4.2 \%$ ether extract and $10.8 \mathrm{MJ}$ of metabolisable energy $/ \mathrm{kg}$ ) and wheat straw to meet/exceed the nutrient requirements (ICAR, 2013). Cows in group $\mathrm{T}_{1}$ were supplemented with technical grade urea at $80 \mathrm{~g} /$ animal/d, while that of $\mathrm{T}_{2}$ received a novel combination of cellulopolymer-coated SRN (Zenitro ${ }^{\mathrm{TM}}$ with $\mathrm{min} .40 \% \mathrm{~N}$ ) at $80 \mathrm{~g}$ and EFE (Kemzyme $^{\circledR}$ containing cellulase, xylanase, glucanase, mannanase and xylanase-potentiating factor) at $4 \mathrm{~g} / \mathrm{animal} / \mathrm{d}$ for a period of 20 days (Table 1). Both the additives were manufactured by Kemin Industries South Asia Pvt. Ltd., Chennai, India. Animals were hand-milked twice a day and quantity of milk produced was recorded daily on individual basis. Similarly, milk composition in terms of fat and solid not fat (SNF) was analysed by EKOMILK analyser (BULTEH 2000 Ltd, Bulgaria). Ad libitum fresh drinking water was made available for all cows throughout the day. Statistical analysis was carried out using Statgraphics Centurion XVI software (version 16.2.04). The data were analysed by t-test and a P-value $<0.05$ was considered statistically significant.

Results showed that milk yield did not differ between cows of groups $\mathrm{T}_{1}$ and $\mathrm{T}_{2}$ (13.8 vs. $15.1 \mathrm{~kg} / \mathrm{d}$; $\mathrm{P}=0.559$; Table 2 ). However, composition of milk expressed as fat and SNF improved $(\mathrm{P}<0.05)$ in group $T_{2}$ than that of $T_{1}$. Furthermore, the economic benefit measured as return on investment (ROI) was found to be 8.3:1 in group $\mathrm{T}_{2}$ (Table 2$)$.

A positive milk response to dietary supplementation is expected when one or many nutrients are deficient in the basal diet, and both the diets fed in the present experiment were similar in all nutrient profile, matrix values and even had similar DMI $(\sim 15 \mathrm{~kg} /$ $\mathrm{d}$; data not shown). This might explain the absence of any effect of supplementation on milk yield.

Despite the diets were balanced to match the current production levels, it is interesting to observe an improvement in milk fat and SNF by $10.9 \%$ and $5.4 \%$, respectively in group $\mathrm{T}_{2}$. This can be justified by the individual role of SRN in improving rumen $\mathrm{N}$ metabolism (AFRC, 1993; Cherdthong and Wanapat, 2010; Mahesh et al. 2017; Salami et al. 2021) and EFE in augmenting fibre digestion (Shekhar et al. 2010) - put together resulting in higher availability of nutrient precursors such as acetate for milk fat (Inostroza et al. 2010) and MCP for milk protein synthesis (Thirumalesh and Krishnamoorthy, 2013). On quantitative terms, it appears that MCP fulfilled approximately $78 \%$ of total protein
Table 1 Ingredient composition of total mixed ration (kg, as-is basis)

\begin{tabular}{lll}
\hline Ingredient & $\mathrm{T}_{1}$ & $\mathrm{~T}_{2}$ \\
\hline Green maize & 30 & 30 \\
Wheat straw & 3 & 3 \\
Concentrate mixture & 8 & 8 \\
Urea & 0.08 & - \\
Slow-release nitrogen & - & 0.08 \\
Exogenous fibrolytic enzyme & - & 0.004 \\
\hline
\end{tabular}

anclusive of micronutrients and additives

Table 2 Production performance and economics of novel additive supplementation in dairy cows $(\mathrm{n}=6)$

\begin{tabular}{lll}
\hline Attribute & $\mathrm{T}_{1}$ & $\mathrm{~T}_{2}$ \\
\hline Production & $13.8 \pm 1.37$ & $15.1 \pm 1.48$ \\
Milk yield (kg/d) & $3.49^{\mathrm{A}} \pm 0.06$ & $3.87^{\mathrm{B}} \pm 0.08$ \\
Fat $(\%)$ & $7.92^{\mathrm{A}} \pm 0.04$ & $8.35^{\mathrm{B}} \pm 0.02$ \\
Solid not fat $(\%)$ & & \\
Economics & 30 & 33 \\
Price of milk (INR/kg) & 414 & 500 \\
Milk revenue (INR/d) & - & 86 \\
Incremental revenue & & 10.4 \\
(INR/animal/d) & & \\
Inclusion cost of additives & - & 8.3 \\
(INR/d) & & \\
Return on investment ${ }^{\mathrm{b}}$ & - &
\end{tabular}

$1 \$=\operatorname{INR} 74$

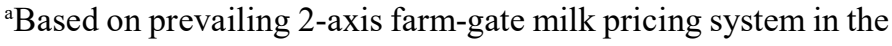
market

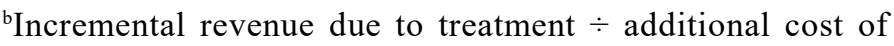
supplementation

Means bearing different superscripts (A, B) in each row differ significantly at $\mathrm{P} \leq 0.05$

requirements ( $1.4 \mathrm{~kg} \mathrm{MCP}$ vs. $1.8 \mathrm{~kg}$ protein requirement/d; ICAR, 2013) assuming a theoretical MCP yield of $170 \mathrm{~g} / \mathrm{kg}$ organic matter fermented in the rumen (DOMR; Blümmel et al. 1999). Indeed, the level of both the NPN sources used were $80 \mathrm{~g}$ representing not $>15 \%$ of total $\mathrm{N}$ intake, which is within the safer dietary inclusion level of $135 \mathrm{~g}$ and/or $20 \%$ of total daily $\mathrm{N}$ intake recommended for dairy cows (Kertz et al. 2010). Furthermore, it is also reasonable that, along with sustained release effect of $\mathrm{NH}_{3}$ by SRN, the fibre degradation carried out by EFE might have additionally supported the availability of fermentable carbohydrates, as has been reported previously (Gado et al. 2009; Shekhar et al. 2010; Meale et al. 2014). In this direction, a recent meta-analysis by TiradoGonzález et al. (2018) conclusively revealed an increase of $99.4 \mathrm{~g}$ milk protein and $83 \mathrm{~g}$ fat per day upon supplementing EFE in dairy cows, as obtained for group $T_{2}$ in the present experiment. According to the best of authors' knowledge, this is the first-ofits-kind of study demonstrating the practical worth of a 
combination of SRN and EFE to benefit milk components in dairy cows under Indian context.

A good 'economic return' is the central determinant of sustainability of any dairy enterprise. As feed alone is factored towards $>60 \%$ of recurring expenses, any dietary regimen is expected to have a direct impact on farm economy. Considering fat and SNF-based 2-axis milk payment system, the outcome of present trial clearly deduces that an ROI of $8.3: 1$ is practically achievable when dairy producers use a novel combination of SRN and EFE for lactating rations. This is principally attributed to an increased farm-gate milk realisation as a result of improved milk composition. Consistent with our findings, when SRN partly substituted soya bean meal, a better income over feed cost was observed in high producing Wisconsin dairy herds (Inostroza et al. 2010).

\section{Conclusions}

It was concluded from this on-farm trial that dairy cows supplemented with a combination of slow-release nitrogen and exogenous fibrolytic enzyme improved milk composition and net economic returns. Future studies may explore the trade-offs between feed cost optimisation with these additives through energy-protein ingredient reformulation and performance measures in dairy cows.

\section{Acknowledgement}

Authors sincerely acknowledge Kemin Industries South Asia Pvt. Ltd., Chennai, India for supporting this study.

\section{Conflicts of interest}

Authors declare that there are no known financial or any other conflicts of interest associated with the data presented in this publication.

\section{References}

AFRC (1993) Energy and protein requirements of ruminants. Agricultural and Food Research Council, CAB International, Wallingford, UK

Blümmel M, Mgomezulu R, Chen XB, Makkar HPS, Becker K, Ørskov ER (1999) The modification of an in vitro gas production test to detect roughage related differences in in vivo microbial protein synthesis as estimated by the excretion of purine derivatives. J Agric Sci (Cambridge) 133: 335-340

Cherdthong A, Wanapapt M (2010) Development of urea products as rumen slow-release feed for ruminant production: a review. Aust J Basic Appl Sci 4: 2232-2241

Gado HM, Salem AZM, Robinson PH, Hassan M (2009) Influence of exogenous enzymes on nutrient digestibility, extent of ruminal fermentation as well as milk production and composition in dairy cows. Anim Feed Sci Technol 154: 36-46

ICAR (2013) Nutrient Requirements of Cattle and Buffalo. Indian Council of Agricultural Research, New Delhi, India
Inostroza JF, Shaver RD, Cabrera VE, Tricárico JM (2010) Effect of diets containing a controlled-release urea product on milk yield, milk composition, and milk component yields in commercial Wisconsin dairy herds and economic implications. Prof Anim Sci 26: 175-180

Kertz AF (2010) Urea feeding to dairy cattle: a historical perspective and review. Prof Anim Sci 26: 257-272

Mahesh MS, Mohini M (2013) Biological treatment of crop residues for ruminant feeding: a review. Afr J Biotechnol 12: 4221-4231

Mahesh MS, Thakur SS, Kumar R, Malik T, Gami R (2017) Nitrogen fractionation of certain conventional- and lesser-known by-products for ruminants. Anim Nutr 3: 186-190

Meale SJ, Beauchemin KA, Hristov AN, Chaves AV, McAllister TA (2014) Opportunities and challenges in using exogenous enzymes to improve ruminant production. J Anim Sci 92: 427-442

NRC (2001) Nutrient requirements of dairy cattle. 7th rev. edn. National Academy Press, Washington, DC, USA

Salami SA, Moran CA, Warren HE, Taylor-Pickard J (2021) Meta-analysis and sustainability of feeding slow-release urea in dairy production. PLoS ONE 16: e0246922

Shekhar C, Thakur SS, Shelke SK (2010) Effect of exogenous fibrolytic enzymes supplementation on milk production and nutrient utilization in Murrah buffaloes. Trop Anim Health Prod 42: 14651470

Thirumalesh T, Krishnamoorthy U (2013) Rumen microbial biomass synthesis and its importance in ruminant production. Int $\mathrm{J}$ Livest Res 3: 5-26

Tirado-González DN, Miranda-Romero LA, Ruíz-Flores A, Medina-Cuéllar SE, Ramírez-Valverde R, Tirado-Estrada G (2018) Meta-analysis: effects of exogenous fibrolytic enzymes in ruminant diets. J Appl Anim Res 46: 771-783 